\title{
ESTIMATION OF LEAD AND CADMIUM LEVELS IN MUSCLES, LIVERS AND KIDNEYS OF SLAUGHTERED CATTLE IN MOSUL CITY
}

Hiba S. Al-naemi

Vet. Public Hlth. Dept., College of Vet. Med., Mosul Univ., Iraq

\begin{abstract}
Lead and cadmium levels were estimated in 225 samples of muscles, livers and kidneys of slaughtered cattle (75 samples of each). The samples were collected from butcher shops in Mosul City and they were analyzed for the presence of these heavy metals by using atomic absorption spectrophotometer. The mean concentrations of lead in muscles, livers and kidneys of slaughtered cattle were $0.071,0.472$ and $0.398 \mathrm{mg} / \mathrm{kg}$, respectively. Of these muscle, liver and kidney samples, $2.67 \%, 17.33 \%$ and $12 \%$ of samples, respectively, were exceeded the permissible limits for lead in these tissues which proposed by the European Commission (EC). Results showed that mean concentrations of lead in livers and kidneys were significantly higher $(p<0.05)$ than that reported in muscles. For cadmium results showed that muscle, liver and kidney samples of slaughtered cattle were contained mean values of $0.009,0.0591$ and 0.0979 $\mathrm{mg} / \mathrm{kg}$, respectively, and that only $1.33 \%$ and $2.67 \%$ of liver and kidney samples exceeded the maximum acceptable limits of the EC, respectively, while all muscle samples contained levels within the EC limit for cadmium. Significant differences $(\mathrm{p}<0.05)$ in the mean concentrations of cadmium were recorded between the studied tissues as the highest mean concentration was reported in the kidneys, then in the livers, while the muscles contained the minimum mean concentration. Also results showed that mean concentrations of lead in muscles, livers and kidneys of slaughtered cattle were significantly higher $(p<0.05)$ than that reported about cadmium in the same tissues, respectively.
\end{abstract}

\section{INTRODUCTION}

Environmental pollution with heavy metals is considered as one of the most important problems as these metals can not be degraded and stay permanently in the environment (Baykov et al., 1996). Finally, heavy metals will be appear in the food chain when they are accumulated in plant and animal tissues (Demirezen and Aksoy, 2004). Lead and cadmium are transmitted from mobile and stationary sources into the air and may reach to human food (Sharkawy and Amal, 2003). So contamination with these metals can be happened most commonly over areas of high traffic density (Mahmood et al., 2007). The polluted meat from edible animal species exposed to heavy metals in the environment is sold in the market for human consumption (Iwegbue, 2008). Much attention has been focused on the presence of these metals in the meat of slaughtered animals due to these metals can not be destroyed by heat treatment (Levensen and Barnard, 1988).

Cattle are mostly at risk of lead poisoning due to the natural curiosity, licking habits, and lack of oral discrimination and these make any available 
lead-containing materials, as discarded batteries, farm machinery grease or oil and caulks or putties, potential sources of poisoning. Lead and other heavy materials tend to lodge in the

\section{Received 2/5/2010 accepted 20/9/2010}

reticulum of ruminant animals. This provides a reservoir from which lead can continue to be absorbed into the bodies of these animals (Radostitis et al., 2007). Sources of lead contamination include lead-based indoor paint in old houses, lead in dust from environmental sources, lead in air from combustion of lead-containing industrial emissions, and hand-to-mouth activities of young children living in contaminated environments (Goyer and Clarkson, 2001). The major exposure to lead for the non-smoking and non-occupationally exposed population is food \& water (Rubio et al., 1999). Lead toxicity can cause colic, constipation and anemia. It may also induce increased blood pressure, cardiovascular disease, liver dysfunction, renal damage and peripheral neuropathy in adults. Foetal neuro-developmental effects and reduced learning capacity in children are among the most serious effects of lead toxicity (Bolger et al., 2000). An increase in the maternal blood lead level may contribute to reducing gestational duration and birth weight. Also lead is immunotoxic and classified as a 2B carcinogen by the International Agency for Research on Cancer (IARC) (Goyer and Clarkson, 2001).

Cadmium and its compounds are toxic substances. It is used in many industrial applications (electroplating, nickel-cadmium batteries, pigments, and plastics) and released into the environment via the incineration of waste materials, the smelting of other metals, and the use of phosphate and sewage sludge fertilizers (Satarug et al., 2003). Foodstuffs and water are the main sources of cadmium exposure for the non-smoking general population (Anke et $a l .$, 2002). The muscles and offals (especially liver and kidney) come at the second class after vegetables as the sources of cadmium in the diet (Coni et al., 1992). Cadmium is primarily toxic to the kidney (Bernard, 2004). Exposure to cadmium has been associated with nephrotoxicity, osteoporosis, neurotoxicity, genotoxicity, teratogenicity, and it has been classified as a human carcinogen (Group 1) by the IARC (Huff et al., 2007; Gallagher et al., 2008).

The present study was planned to determine the prevalence of lead and cadmium in muscles, livers and kidneys of cattle slaughtered in Mosul City which are the items of every day consumption in human food and also to compare the obtained values with the acceptable limits proposed by EC.

\section{MATERIALS AND METHODS}

A total of 225 random beef muscle, liver and kidney samples (75 samples of each) were collected in January-June 2009 from butcher shops situated in different regions of Mosul City. During sampling, the age, sex and feeding habits of the animals were not taken into account. The samples were put in plastic bags and conveyed to the laboratory. Gross fat, connective tissue and major blood vessels were removed and stored at $-18{ }^{\circ} \mathrm{C}$ until required (Lopez Alonso et al., 2000). 
Each tissue sample was ground \& homogenized according to AlBaggou' (2002). One gram from each homogenized sample was digested in a Pyrex beaker with $7 \mathrm{ml}$ of a mixture of ultra pure concentrated nitric acid: perchloric acid $\left(\mathrm{HNO}_{3}: \mathrm{HCLO}_{4}\right)$ at a ratio of (6:1) and was placed on a hotplate at $135{ }^{\circ} \mathrm{C}$ for $2 \mathrm{~h}$. Care must be exercised with fatty materials to maintain excess nitric acid until most of the organic matter is destroyed. The liquor formed was evaporated slowly to near dryness (avoiding prolonged baking), cooled and dissolved in $1 \mathrm{ml}$ of $20 \%$ nitric acid and diluted with $5 \mathrm{ml}$ of the deionized water. The solution was analyzed for lead and cadmium using atomic absorption spectrophotometer (PYE UNICAM-SP9) (Iwegbue, 2008).

The data were statistically analyzed using sigma stat for windows version 3.10 (2004). The differences in the mean concentrations for each heavy metal in muscle, liver and kidney tissues were compared by one-way analysis of variance and Duncan's multiple range test. On the other hand, Student t-test was used to compare the differences in the mean concentrations of lead and cadmium in the tissue of the same source (Petrie and Watson, 2003).

\section{RESULTS AND DISCUSSION}

In the present study, the obtained results (Table 1) revealed that the range and mean lead concentrations in bovine muscle, liver and kidney samples were $0.01-1.12(0.071), 0.07-6.12(0.472)$ and $0.09-5.56(0.398) \mathrm{mg} / \mathrm{kg}$, respectively. The number and percentage of samples exceeded the maximum acceptable limits for lead as proposed by the EC in bovine muscles, livers and kidneys (Anonymous, 2001) were illustrated in table (2) which verify that from (75) samples of each tissue only (2) samples of muscles (2.67\%) exceeded the maximum permissible limit for lead in muscle as proposed by the EC $(0.1$ $\mathrm{mg} / \mathrm{kg}$ ), while there was (13) samples of livers (17.33\%) and (9) samples of kidneys (12\%) containing lead concentrations higher than the EC limits for lead in liver and kidney $(0.5 \mathrm{mg} / \mathrm{kg})$. These results are nearly similar to those reported by Kottferova and Korenekova (1995) who examined lead concentration in the muscles and organs of slaughtered cattle and reported mean lead levels of $0.08,0.55$ and $0.35 \mathrm{mg} / \mathrm{kg}$ in muscles, livers and kidneys of cattle, respectively.

Table (1): Range and mean concentrations $(\mathrm{mg} / \mathrm{kg}$ ) of lead and cadmium in bovine muscles, livers and kidneys

\begin{tabular}{|c|c|c|c|c|c|}
\hline \multirow{2}{*}{$\begin{array}{c}\text { Type of } \\
\text { examined } \\
\text { samples }\end{array}$} & \multirow{2}{*}{$\begin{array}{c}\text { No. of } \\
\text { samined } \\
\text { samples }\end{array}$} & \multicolumn{2}{|c|}{ Pb } & \multicolumn{2}{c|}{$\mathrm{Cd}$} \\
\cline { 3 - 6 } Muscle & 75 & $0.01-1.12$ & $\begin{array}{c}0.071 \pm \\
0.0166 \mathrm{a}\end{array}$ & $0.004-0.05$ & $\begin{array}{c}0.009 \pm \\
0.00116 \mathrm{c}\end{array}$ \\
\hline Liver & 75 & $0.07-6.12$ & $\begin{array}{c}0.472 \pm \\
0.0876 \mathrm{~b}\end{array}$ & $0.008-0.74$ & $\begin{array}{c}0.0591 \pm \\
0.0127 \mathrm{~d}\end{array}$ \\
\hline Kidney & 75 & $0.09-5.56$ & $\begin{array}{c}0.398 \pm \\
0.0778 \mathrm{~b}\end{array}$ & $0.01-1.05$ & $\begin{array}{c}0.0979 \pm \\
0.0197 \mathrm{e}\end{array}$ \\
\hline
\end{tabular}

- Vertically different letters are significantly different at $(\mathrm{p}<0.05)$ 
- Horizontally different letters are significantly different at $(\mathrm{p}<0.05)$

The results of the present study were higher than those noticed by Iwegbue (2008) in southern Nigeria who reported that livers and kidneys of cattle were generally have low lead levels $(75 \%$ of the liver and kidney samples have lead concentrations less than $0.001 \mathrm{mg} / \mathrm{kg}$ ) and recorded range and mean concentrations of nd-1.23 (0.08) $\mathrm{mg} / \mathrm{kg}$ in livers and nd-0.95 $(0.04) \mathrm{mg} / \mathrm{kg}$ in kidneys.

Table (2): Number and percentage of bovine muscle, liver and kidney samples exceeding the maximum permissible limits for lead and cadmium as proposed by the European Commission (EC)

\begin{tabular}{|c|c|c|c|c|}
\hline \multirow{3}{*}{ Metal } & $\begin{array}{c}\text { Type of } \\
\text { examined } \\
\text { samples }\end{array}$ & $\begin{array}{c}\text { No. of } \\
\text { examined } \\
\text { samples }\end{array}$ & $\begin{array}{c}\text { No. of samples } \\
\text { exceeding the EC } \\
\text { limits }\end{array}$ & $\begin{array}{c}\text { \% of samples } \\
\text { exceeding the } \\
\text { EC limits }\end{array}$ \\
\hline \multirow{3}{*}{ Lead } & Muscle & 75 & 2 & 2.67 \\
\cline { 2 - 5 } & Liver & 75 & 13 & 17.33 \\
\cline { 2 - 5 } & Kidney & 75 & 9 & 12 \\
\hline \multirow{3}{*}{ Cadmium } & Muscle & 75 & 0 & 0 \\
\cline { 2 - 5 } & Liver & 75 & 1 & 2.33 \\
\cline { 2 - 5 } & Kidney & 75 & 2 & \\
\hline
\end{tabular}

The levels of lead reported in this study were lower than levels reported by Mariam et al. (2004) who showed mean lead concentrations of 2.19, 2.18 and $2.02 \mathrm{mg} / \mathrm{kg}$ for muscles, livers and kidneys, respectively, of beef in Lahore and also lower than those showed by Adei and Forson-Adaboh (2008) who reported that all liver samples exceeded the EC limit for lead as it ranged from $1.3-13.8 \mathrm{mg} / \mathrm{kg}$ in the livers of some domestic animals including cows in Ghana.

Lead is stored mainly in the liver and kidney, and normal muscle lead value appears to be much lower than that reported in these tissues (Doyle and Spaulding, 1978). Other studies gave same results as in the study done by Stabel-Tancher et al. (1975) which showed that lead concentration was 0.12 $\mathrm{mg} / \mathrm{kg}$ in muscle of Finnish cattle, $0.28 \mathrm{mg} / \mathrm{kg}$ in liver and $0.26 \mathrm{mg} / \mathrm{kg}$ in kidney, in addition to the study performed by Kottferova and Korenekova (1995) which presented the same results. Results reported in this study were in agreement with those reported above as mean lead concentrations in livers and kidneys were significantly higher $(\mathrm{p}<0.05)$ than that recorded in muscles (Table 1).

In this study, the results presented in Tables (1) and (2) showed that the range and mean cadmium levels in muscles, livers and kidneys of slaughtered cattle were 0.004-0.05 (0.009), 0.008-0.74 (0.0591) and 0.01-1.05 (0.0979) $\mathrm{mg} / \mathrm{kg}$, respectively, and that all samples of bovine muscles contain concentrations within the acceptable EC limit $(0.05 \mathrm{mg} / \mathrm{kg})$, whereas only (1) sample of livers $(1.33 \%)$ and (2) samples of kidneys $(2.67 \%)$ exceeded the limits for cadmium in liver and kidney ( 0.5 and $1 \mathrm{mg} / \mathrm{kg}$, respectively) 
established in the EC (EC, 2001). Results are in agreement to certain extent to the results observed by Rahimi and Rokni (2008) who mentioned that the mean concentrations of cadmium in bovine muscles, livers and kidneys in Isfahan were $0.0033,0.0497$ and $0.1371 \mathrm{mg} / \mathrm{kg}$, respectively. Also results are nearly similar to those reported by Iwegbue (2008) who found that mean cadmium level in kidneys of cattle in southern Nigeria was $0.14 \mathrm{mg} / \mathrm{kg}$, but all samples contained cadmium levels below the limit of EC.

Results were higher than those found by Kreuzer et al. (1985) in Germany who reported that bovine muscles contained between 0.0005 and $0.0006 \mathrm{mg} / \mathrm{kg}$ cadmium, while livers were shown to accommodate between 0.005 and $0.31 \mathrm{mg} / \mathrm{kg}$ cadmium and that all muscle and liver samples contained levels lower than the permissible limits for cadmium. The current results on the other hand, were lower than the results observed by Langlands et al. (1988) who recorded that the concentrations of cadmium in the residue survey organized by the Australian Bureau of Rural Science at meat works throughout Australia averaged $0.03,0.18$ and $0.65 \mathrm{mg} / \mathrm{kg}$ in bovine muscle, liver and kidney, respectively. In addition to the results reported by Lopez Alonso et al. (2000) who found that mean cadmium levels in livers and kidneys of cattle in Spain were 0.086 and $0.407 \mathrm{mg} / \mathrm{kg}$, respectively, and to the results presented by Mariam et al. (2004) who refered that mean cadmium concentrations in the muscles, livers and kidneys of beef in Lahore were $0.33,0.42$ and $0.909 \mathrm{mg} / \mathrm{kg}$, respectively, where they also were higher than the current results.

Results showed significant differences $(\mathrm{p}<0.05)$ in the mean concentrations of cadmium between the studied tissues as the highest mean cadmium concentration was reported in the kidneys, then in the livers, while the minimum mean concentration was reported in the muscles (Table 1). Several studies have shown same results, as in the study reported by Falandysz (1993) which showed that mean cadmium levels in the muscle, liver and kidney samples of cattle in Poland reached values of $0.005,0.106$ and $0.542 \mathrm{mg} / \mathrm{kg}$, respectively. Also Kottferova and Korenekova (1995) indicated that muscles contained only small amounts of cadmium, whereas kidneys accommodated 45 times more. Finally, Rahimi and Rokni (2008) stated that mean cadmium concentrations in the livers and kidneys were 15.06 and 41.54 times, respectively, higher than that in the muscles of slaughtered cattle. Animals exposed to cadmium accumulate it in their livers and kidneys as their free protein-thiol group content leads to a strong fixation of heavy metals. Despite the excretory mechanism for such metals, which is based on low molecular compounds with-SH groups, vertebrates could not develop this mechanism during the period of evolution to the extent necessary for today's anthropogenic sources of pollution (Pompe-Gotal and Crnic, 2002). Furthermore, Satarug et al. (2003) pointed that the higher accumulation of cadmium in the kidney is due to the detoxification function of this organ and that kidney is considered as a target organ for cadmium toxicity. Although muscles contained the least concentrations of lead and cadmium, but because of the large size which it comprise, muscles may be considered as one of the high concentrated tissues in comparable with the total content of the body, and considered in addition to 
liver and kidney one of the tissues which have the longest biological half life (Shaikh and Smith, 1980).

Many studies conducted in Mosul City revealed that environmental pollution with lead metal was higher than that for cadmium (Al-Saffawi, 2006; Mahmood et al., 2007), so cattle will be more exposure to lead than cadmium and higher lead levels will be accumulate in their tissues (Dudka and Miller, 1999) or pollute their muscles and offals after slaughtering (Sharkawy and Amal, 2003). The present study showed similar results (Table 1).

The results reflect different levels of lead and cadmium in the samples of muscles, livers and kidneys of slaughtered cattle and this may be attributed to the pasture on which these animals grazed, the source of water from which these animals drank, the age of animals from which these samples obtained, and the site of butcher shop on which these slaughtered animals were offered to consumers.

Finally, although low percentage of samples exceeded the permissible limits for lead and cadmium but preventive measures should be taken in order to prevent human exposure to levels higher than the permissible limits for these toxic metals by preventing grazing of animals and offering of carcasses and offals near high traffic density areas, avoiding contamination of water sources with industrial wastes, and control the use of pesticides, fungicides as well as phosphate and sewage sludge fertilizers to reduce the pollution with these metals.

\section{تقدير مستويات الرصاص والكادميوم في عضلات وأكباد وكلى الأبقار المذبوحة في مدينة الموصل

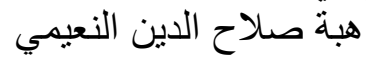 \\ فرع الصحة العامة البيطرية / كلية الطب البيطري / النعامعة الموصل ــ العراق}

\section{الخلاصة}

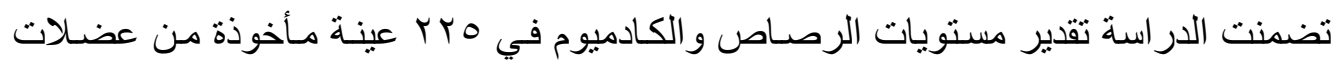

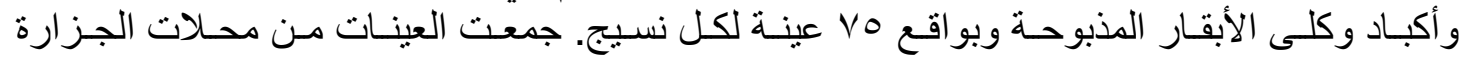

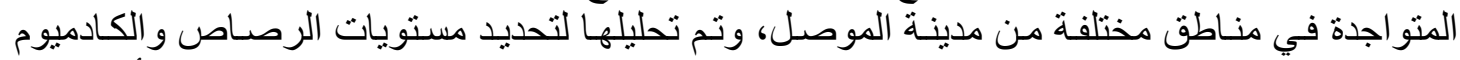

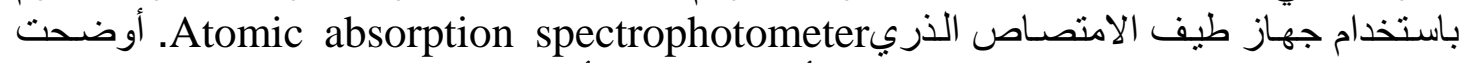

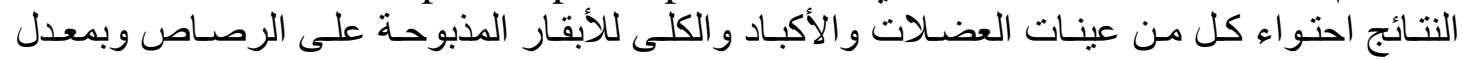

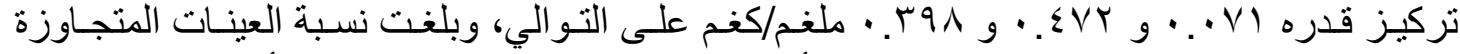

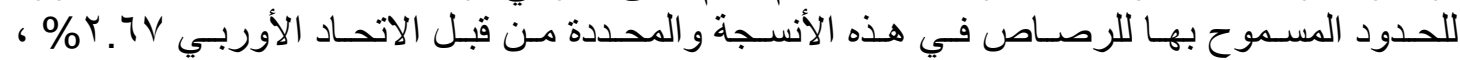

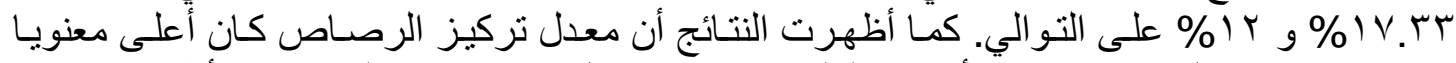

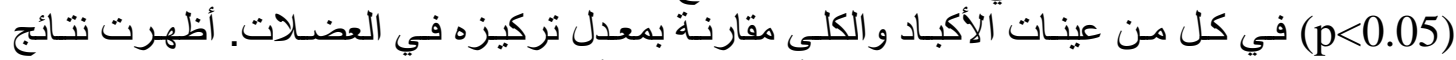

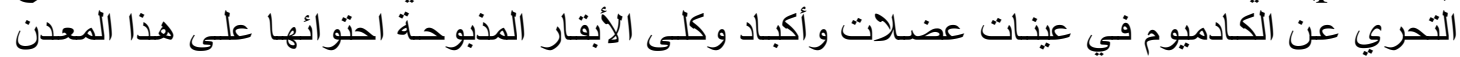

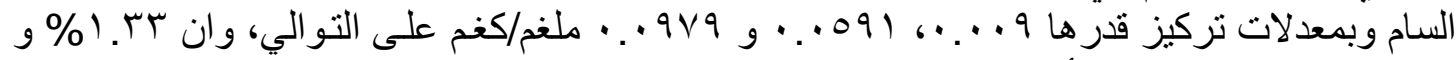
الانج.TV

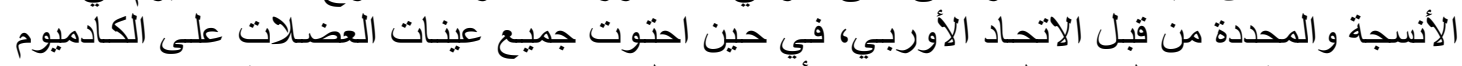

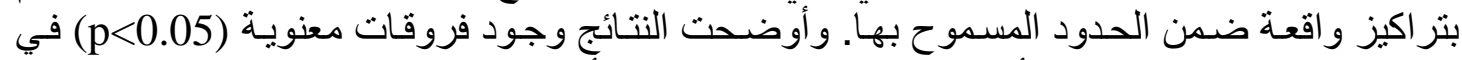

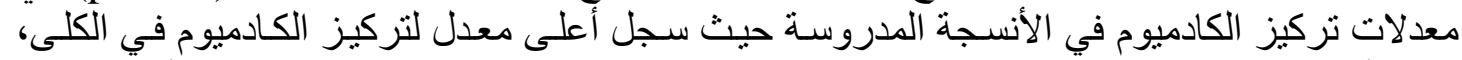

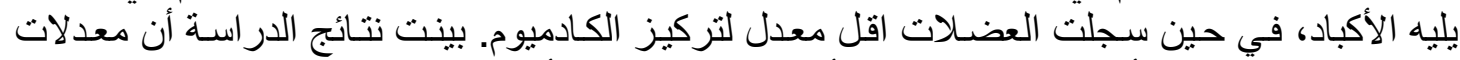

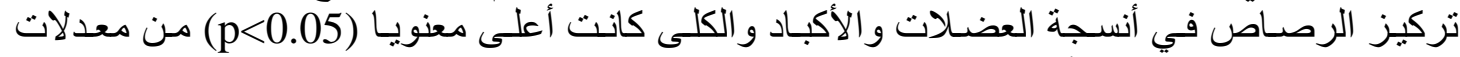
تركيز الكادميوم في نفس الأنسجة على التوالي. 


\section{ACKNOWLEDGMENTS}

Author wish to thank the College of Veterinary Medicine, University of Mosul for support and providing facilities. Appreciation is also extended to the Department of Biology, College of Science, University of Mosul for allowance to analyze samples with atomic absorption spectrophotometer.

\section{REFERENCES}

Adei, E. and K. Forson-Adaboh (2008). Toxic ( $\mathrm{Pb}, \mathrm{Cd}, \mathrm{Hg}$ ) and essential (Fe, $\mathrm{Cu}, \mathrm{Zn}, \mathrm{Mn}$ ) metal content of liver tissue of some domestic and bush animals in Ghana. Food Addit. Contam. B1(2): 100 - 105.

Al-Baggou', B.K. (2002). Neurobehavioral and Biochemical Changes Induced By Interaction Between Cadmium And Some Insecticides In Mice. Ph.D. Dissertation, College of Vet. Med., Mosul University, Mosul, Iraq, 35 p.

Al-Saffawi, A.Y. (2006). Environmental Pollution Of Mosul City And Methods Of Remediation. Ph.D. Dissertation, College of Education, Mosul University, Mosul, Iraq.

Anke, M.; M. Mueller; A. Truepschuch and R. Mueller (2002). Intake and effects of cadmium, chromium and nickel in humans. J. Commodity Sci. 41(1): 41-63.

Anonymous (2001). Commission regulation (EC) no, 466/2001 of 8 March 2001 setting maximum levels for certain contaminants in foodstuffs. Off. J. Eur. Communities Legis. 77: 1-13.

Baykov, B.D.; M.P. Stoyanov and M.L. Gugova (1996). Cadmium and lead bioaccumulation in male chickens for high food concentrations. Toxicol. Environ. Chem. 54: 155-9.

Bernard, A. (2004). Renal dysfunction induced by cadmium: biomarkers of critical effects. Biometals. 17 (5): 519-523.

Bolger, M.; C. Carrington; J.C. Larsen and B. Petersen (2000). Safety evaluation of certain food additives and contaminants: lead. WHO Food Addit. Series. 44: 273-312.

Coni, E.; M. Baldaini; P. Stacchini and F. Zanasi (1992). Cadmium intake with the diet in Italy: a pilot study. J. Trace Elem. Electrolytes Hlth. Dis. 6: $175-181$.

Demirezen, D. and A. Aksoy (2004). Accumulation of heavy metals in Typha angustifolia (L.) and Potamogeton pectinatus (L.) living in Sultan Marsh (kayseri, Turkey). Chemosphere. 56: 685- 696.

Doyle, J.J. and J.E. Spaulding (1978). Toxic and essential trace elements in meat: a review. J. Anim. Sci. 47: 398-419.

Dudka, S. and W.P. Miller (1999). Accumulation of potentially toxic element in plants and their transfer to human food chain. J. Environ. Sci. Hlth. B34 (4): 681-708.

Falandysz, J. (1993). Some toxic and essential trace metals in cattle from the northern part of Poland. Sci. Total Environ. 136: 177-191. 
Gallagher, C.M.; J.S. Kovach and J.R. Meliker (2008). Urinary cadmium and osteoporosis in U.S. Women >or= 50 years of age: NHANES 1988-1994 and 1999-2004. Environ. Hlth. Perspect. 116 (10), 1338-1343.

Goyer, R.A. and T.W. Clarkson (2001). Toxic effects of metals. In: Klaassen, C. D. ed. "Casarett and Doull's Toxicology: The Basic Science Of Poisons" 6th ed., McGraw-Hill companies, Inc. , USA, pp: 811-868.

Huff, J.; R.M. Lunn; M.P. Waalkes; L. Tomatis and P.F. Infante (2007). Cadmium-induced cancers in animals and in humans. Int. J. Occup. Environ. Hlth. 13 (2): 202-212.

Iwegbue, C.M. (2008). Heavy metal composition of livers and kidneys of cattle from southern Nigeria. Vet. Arhiv. 78 (5): 401-410.

Kottferova, J. and B. Korenekova (1995). The effect of emissions on heavy metals concentrations in cattle from the area of an industrial plant in Slovakia. Arch. Environ. Contam. Toxicol. 29: 400-405.

Kreuzer, W.; B. Sansoni; W. Kratcke and P. Wissmath (1985). Cadmium in the muscles and organs of the slaughtered cattle. Fleischwirtschaft. 55: 387396. (Abstract).

Langlands, J. P.; G. E. Donald and J. E. Bowles (1988). Cadmium concentrations in liver, kidney and muscle in Australian sheep and cattle. Aust. J. Exp. Agri. 28: 291-297.

Levensen, H. and W. Barnard (1988). "Wastes in Marine Environment", Hemisphere Publishing Corporation, Cambridge, London, pp: 123-126.

Lopez Alonso, M.; J.L. Benedito; M. Miranda; C. Castillo; J. Hernandez and K.F. Shove (2000). Toxic and trace elements in liver, kidney and meat from cattle slaughtered in Galicia (NW Spain). Food Addit. Contam. 17: 447-457.

Mahmood, T.A.; S.S. Abdelwahab and R.M. Al-Obaidi (2007). Air pollution and rainwater properties in Mosul City. Al-Rafidain Engineering. 15 (3): 21-31.

Mariam, I.; S. IQBAL and S.A. NAGRA (2004). Distribution of some trace and macrominerals in beef, mutton and poultry. Int. J. Agric. Biol., 6: 816-820.

Petrie, A. and P. Watson (2003). "Statistics for veterinary and animal science", Blackwell Science, London.

Pompe-Gotal, J. and A. P. Crnic (2002). Cadmium in tissue of roe deer (Capreolus capreolus) in Croatia. Vet. Arhiv. 72: 303-310.

Radostitis, O.M.; C.C. Gay; K.W. Hinchcliff and P.D. Constable (2007). "Veterinary Medicine: A Textbook of the Disease of Cattle, Horses, Sheep, Pigs and Goats" $10^{\text {th }}$ ed., Saunders, Elsevier, Spain, pp: 17991808.

Rahimi, E. and N. Rokni (2008). Measurement of cadmium residues in muscle, liver and kidney of cattle slaughtered in Isfahan abattoir using grafite furnace atomic absorption spectrometry (GFAAS): a preliminary study. Iranian J. Vet. Res., 9(2), 174-177.

Rubio, C.; I. Frias and A. Hardisson (1999). Lead toxicology and its presence in food. Alimentaria. 305, 77-85. 
Satarug, S.; J.R. Baker; S. Urbenjapol; M. Haswell-Elkins; P.E. Reilly; D.J. Williams and M.R. Moore (2003). A global perspective on cadmium pollution and toxicity in non-occupationally exposed population. Toxicol. Lett. 137(1-2): 65-83.

Shaikh, Z. A. and J. C. Smith (1980). Metabolism of orally ingested cadmium in humans. In: Holmstedt, B.; Lauwerys, B.; Mercier, M.; Roberfroid, M. eds. "Mechanism of Toxicity and Hazard Evaluation", Biomedical press, Amsterdam, pp: 569-574.

Sharkawy, A.A. and A.M. Amal (2003). Lead and cadmium levels in some ready-to-eat meat products (shawerma and hamburger) at Assiut City. Assiut Vet. Med. J. 49 (99): 105-112.

Stabel-Tancher, R.; E. Nurmi and E. Karppanen (1975). Content of copper, zinc, lead, cadmium and mercury in muscle, liver and kidney of Finnish cattle. J. Sci. Agr. Soc. 47: 469. 